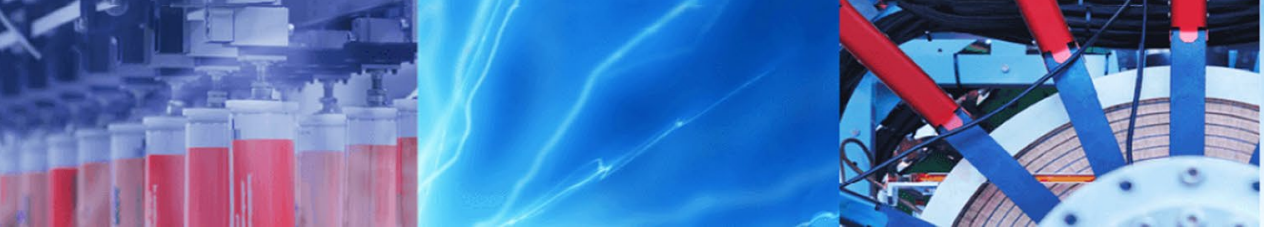

Research Article

\title{
In vitro antioxidant activity of synthesized BSA conjugated manganese dioxide nanoparticles
}

\author{
Sonali Pardhiya ${ }^{1} \cdot$ Eepsita Priyadarshini $^{1} \cdot$ Paulraj Rajamani $^{1}$
}

Received: 7 April 2020 / Accepted: 21 August 2020 / Published online: 31 August 2020

(c) Springer Nature Switzerland AG 2020

\begin{abstract}
Nanozymes represent the class of nanomaterials exhibiting enzyme mimicking properties. Biocompatible nanozymes with the ability to imitate antioxidant enzymes hold tremendous possibility for development of therapeutics in various disorders related to stress. In the present work we synthesized $\mathrm{BSA}$ templated $\mathrm{MnO}_{2}$ nanoparticles. Synthesized nanoparticles was found to mimic antioxidant enzymes viz, superoxide dismutase, catalase and peroxidase. Additionally, it also showed oxidase mimicking activity. Nanoparticles were assessed for cytotoxicity by MTT assay in mammalian cells by treating human embryonic kidney cells (HEK 293) at varying doses and time period. Morphological variations induced after treatment of HEK 293 with nanoparticles was analyzed by transmission electron microscopy. Nanoparticles at $50 \mu \mathrm{g} / \mathrm{mL}$ concentration were found to significantly increase viability of HEK 293 cells compared to control due to their inherent antioxidant property. But at higher doses nanoparticles induced toxicity. This may be due to the intrinsic oxidase mimicking activity of the nanoparticles which suggest that at higher doses nanoparticle has cross over role as pro-oxidant. Additionally, there was no visible morphological alteration in TEM micrograph of treated cells. The results indicated that the $\mathrm{BSA}$ template $\mathrm{MnO}_{2}$ particles act as pro-oxidant at higher doses due to its oxidase mimicking property however, at an optimum dose it functions as therapeutic under stress related conditions due to its anti-oxidant property.
\end{abstract}

Keywords Manganese dioxide $\cdot$ Bovine serum albumin · Antioxidant · Nanozymes · Reactive oxygen species · Prooxidant

\section{Introduction}

Biological enzymes are macromolecules that catalyse biochemical reactions in natural systems, basically by lowering activation energy, resulting in enhancement of the reaction kinetics. However, there are limited applications of these biological enzymes due to stability issues, high cost of synthesis and purification. As a substitute to these natural enzymes, researchers focus on utilization of chemical molecules such as cyclodextrins, metal-complexes, porphyrins, polymeric and supramolecular ligands that exhibit high catalytic power [1, 2]. Conversely, there are issues regarding their catalytic efficiency and biocompatibility that limits its application [3]. Since last decade, artificial enzymes are being investigated as nontoxic, stable and cost-effective solution to chemical and natural enzymes. Breslow coined the term "artificial enzymes" for enzyme mimics that replicate the essential principles of natural enzymes with alternate materials [4]. Pasquato and coworkers initially coined the term "nanozymes" to explain the thiol monolayer covered goldclusters that exhibited ribonuclease mimicking activity [5]. Nanomaterials based enzymes or nanozymes have found wide applications in fields of biosensing, cancer diagnostics, therapy, immunoassays, stem cell growth, neuroprotection and pollutant removal $[6,7]$. A number of nanomaterials such as palladium and gold nanoparticles, fullerene derivatives, rare earth nanoparticles and ferromagnetic nanoparticles,

Paulraj Rajamani, paulraj@@mail.jnu.ac.in | ${ }^{1}$ School of Environmental Sciences, Jawaharlal Nehru University, New Delhi 110067, India. 
were found to exhibit enzyme-like activity [5, 8-12]. Stimuli-responsive $\mathrm{MnO}_{2}$ (manganese dioxide) based nanomaterials have been used for cancer diagnosis and treatments $[13,14]$. Albumin template $\mathrm{MnO}_{2}$ nanomaterials have been used for tumor imaging and elimination where they acted as $\mathrm{pH} / \mathrm{H}_{2} \mathrm{O}_{2}$ stimuli-responsive nanoplatforms [15]. Albumin template nanoparticles have also been studied as potential therapeutic agents [16].

Reactive oxygen species (ROS) are formed when oxygen is reduced incompletely. It includes species like superoxide $\left(\mathrm{O}_{2}^{-}\right)$, hydroxyl radical $(\mathrm{HO})$ and hydrogen peroxide $\left(\mathrm{H}_{2} \mathrm{O}_{2}\right)$. These species are highly reactive, hence are thought to mediate oxygen toxicity. At basal levels they serve as intracellular signalling molecules and are essential for normal physiological process [17]. A healthy cell controls excess ROS by antioxidant defence system that includes enzymes like superoxide dismutase (SOD), glutathione peroxidase (GPx), catalase (CAT), and small molecule antioxidants like vitamins $C$ and $E$, glutathione, etc.[18]. However, when the antioxidant system is not able to control excess ROS, it results in oxidative stress. Several pathological conditions like diabetes, cancer, cardiovascular and neurodegenerative diseases, ageing etc. result from damaged biomolecules such as DNA, proteins and lipids are caused by oxidative stress [19-21]. Hence, it is imperative to maintain redox equilibrium in a cell to combat oxidative stress.

An inherent function of nanozymes is that they possess antioxidant mimicking properties and hence have the potential to protect cells from reactive oxygen mediated damage in cases where the antioxidant system of cell fails [22]. Enzymes like heme peroxidase, oxidases, CAT or SOD mimicking nanomaterials have been reported earlier $[6$, 11, 23-25]. SOD scavenges superoxide anions and CAT catalyses decomposition of excess $\mathrm{H}_{2} \mathrm{O}_{2}$ to water and oxygen. Peroxidase enzymes detoxify free radicals (e.g., glutathione peroxidase) and defend the cells against invading pathogens (e.g., myeloperoxidase). Oxidase enzymes catalyzes oxidation of substrate by oxygen and produces water or hydrogen peroxide [3]. Recently, $\mathrm{Mn}_{3} \mathrm{O}_{4}$ nanoparticles were reported to mimic SOD, CAT and GPx enzymes. These nanoparticles were able to protect the cells from neurotoxin 1-methyl-4-phenylpyridinium (MPP+), that induce neurodegenerative disease i.e. Parkinson's, as it interferes with mitochondrial oxidative phosphorylation [26]. It is thus essential to develop a nanoparticle that can mimic all the major antioxidant enzymes (SOD, CAT and GPx) due to the differential affinity of the enzymes towards ROS [22].

The present study, thus aimed to synthesize bovine serum albumin (BSA) fabricated manganese dioxide nanoparticles (BSA-MnO ${ }_{2} \mathrm{NPs}$ ), characterize and investigate its enzyme mimicking property. Various analytical characterization methods were used for physicochemical analysis of synthesized NP. Additionally, a number of in vitro assays
(SOD, catalase, peroxidase) were performed for determining the antioxidant property of $\mathrm{BSA}-\mathrm{MnO}_{2} \mathrm{NPs}$. Moreover, we also analysed the in vitro viability assay of the synthesized NPs on human embryonic kidney (HEK 293) cells.

\section{Methodology}

\subsection{Preparation of $\mathrm{BSA}^{-\mathrm{MnO}_{2}} \mathrm{NPs}$}

The BSA-MnO ${ }_{2}$ NPs were synthesized according to Liu and colleagues with slight modifications [12]. Briefly, $25 \mathrm{mg} \mathrm{BSA}$ was dissolved in $10 \mathrm{~mL}$ of $0.01 \mathrm{M}$ Phosphate buffer saline (PBS), and then $50 \mu \mathrm{L}$ of the precursor manganese salt $(100 \mathrm{mM})$ was added. The reaction mixture was allowed to stir for $2 \mathrm{~min}$ at room temperature. $770 \mu \mathrm{L}$ of Sodium Hydroxide ( $\mathrm{NaOH})(1 \mathrm{M})$ was then added and again stirred for $6 \mathrm{~h}$. The solution was thereafter dialyzed in double distilled water for $48 \mathrm{~h}$ in order to remove unreacted salts and centrifuged at $18,500 \mathrm{rpm}$ for $30 \mathrm{~min}$. The obtained NPs were suspended in PBS and stored at $4{ }^{\circ} \mathrm{C}$ for future use.

For optimization of synthesis protocol, we used three salts of manganese (manganese chloride, manganese acetate and manganese sulphate) as precursors. For analysing the variation in size and morphology of $\mathrm{BSA}-\mathrm{MnO}_{2}$ nanoparticles, we varied BSA concentration $(2.5 \mathrm{mg} / \mathrm{mL}$, $5 \mathrm{mg} / \mathrm{mL}, 7.5 \mathrm{mg} / \mathrm{mL}$ and $10 \mathrm{mg} / \mathrm{mL}$ ) and characterized the synthesized nanoparticles.

\subsection{Instrumentation}

Various analytical characterizations were performed to analyse the optical and physio-chemical nature of synthesized nanoparticles. UV-visible spectra were recorded from 200 to $600 \mathrm{~nm}$ in UV1800 Shimadzu Spectrophotometer. Fluorescence spectra were recorded in RF-5301PC Shimadzu spectrofluorophotometer. Size and morphology of nanoparticles was observed with Transmission electron microscope (TEM) (JEOL-JEM-2100F) operated at $200 \mathrm{kV}$ and Scanning electron microscope (SEM) (ZEISS, GERMANY EV-40) equipped with a tungsten filament. Dynamic Light Scattering (DLS) was used to determine the hydrodynamic size $\left(R_{\mathrm{h}}\right)$ of nanoparticles. Experiment was performed at room temperature $\left(25^{\circ} \mathrm{C}\right)$ at $\theta=90^{\circ}$ and laser wavelength $647 \mathrm{~nm} . R_{\mathrm{h}}$ was calculated using the Stokes-Einstein equation (Photochor), details of which can be referred from Priyadarshini and Rawat [27]. Zeta potential was determined on a ZEECOM instrument (USA), operating in the range of -200 to $200 \mathrm{mV}$. Experiment was performed at $25^{\circ} \mathrm{C}$, the sample $\mathrm{pH}$ was 6.7 and 100 particles were analysed. Elemental composition was analysed by using energy dispersive X-ray (EDX-200). Fourier transform infrared 
spectroscopy (FTIR) was performed on Agilgent Cary FTIR Spectrophotometer in the range of $400-4000 \mathrm{~cm}^{-1}$.

\subsection{Assessment of antioxidant potential of $\mathrm{BSA}-\mathrm{MnO}_{2} \mathrm{NPs}$}

The BSA-MnO $\mathrm{M}_{2} \mathrm{NPs}$ were assessed for various antioxidant enzyme activities. Oxidase, peroxidase and superoxide dismutase assays were performed on UV1800 Shimadzu spectrophotometer. Catalase assay was conducted on fluorescence spectrophotometer.

\subsubsection{Peroxidase mimicking activity}

Peroxidase mimicking activity of $\mathrm{BSA}-\mathrm{MnO}_{2}$ was investigated using $o$-phenylenediamine (OPD) as a chromogenic substrate with hydrogen peroxide. Upon oxidation, the substrate turns yellow in color. To $0.2 \mathrm{M}$ acetate buffer $(\mathrm{pH}=4.0)$, different concentration of nanoparticle $(25,50$, $100,150,200,250,300 \mu \mathrm{g} / \mathrm{mL}), 20 \mathrm{mM}$ OPD and $1 \mathrm{mM}$ $\mathrm{H}_{2} \mathrm{O}_{2}$ was added and the absorbance slope was recorded at $450 \mathrm{~nm}$ for $3 \mathrm{~min}$ [12].

\subsubsection{Superoxide dismutase mimicking activity}

Superoxide dismutase activity of $\mathrm{BSA}-\mathrm{MnO}_{2} \mathrm{NPs}$ was evaluated by measuring the inhibition of photoreduction of nitro blue tetrazolium (NBT), a method described by Beyer and Fridovich [28]. The superoxide source was created by reduction of photochemically excited riboflavin to a semiquinone, which donates an electron to oxygen. The superoxide readily reacts with NBT to form a purple formazan product that can be measured at $550 \mathrm{~nm}$. A superoxide scavenger prevents the conversion of NBT to formazan [29]. 0.01 M methionine, $1 \mathrm{mM}$ riboflavin and $2 \mathrm{mM}$ NBT was prepared in $50 \mathrm{mM}$ phosphate buffer $(\mathrm{pH}=7.8)$. Care was taken to prevent light exposure to riboflavin. $0.1 \mathrm{~mL}$ nanoparticle (final concentration in reaction volume $25,50,100,150,200,250$, $300 \mu \mathrm{g} / \mathrm{mL}$ ) was added to $2.5 \mathrm{~mL}$ methionine followed by $0.1 \mathrm{~mL}$ NBT and $0.3 \mathrm{~mL}$ riboflavin. The reaction mixture was incubated for $15 \mathrm{~min}$ in light and absorbance recorded at $550 \mathrm{~nm}$. Control set was prepared, where nanoparticle was replaced with PBS. Percentage inhibition of NBT reduction by different concentration of nanoparticles was calculated as per Eq. 1

Inhibition of NBT reduction $(\%)=\left[\left(\mathrm{A}_{\text {sample }}-\mathrm{A}_{\text {control }}\right) / \mathrm{A}_{\text {control }}\right] * 100$

\subsubsection{Oxidase mimicking activity}

Oxidase mimicking activity was investigated using its chromogenic substrate, 3,3',5,5'-Tetramethylbenzidine (TMB). On oxidation, the substrate turns blue in color. Different concentration of nanoparticles were added (final concentration in reaction volume $25,50,100,150,200$, $250,300 \mu \mathrm{g} / \mathrm{mL})$ to citrate buffer $(0.2 \mathrm{M}, \mathrm{pH}=4.0)$ respectively, followed by $20 \mathrm{mM} \mathrm{TMB}$. The absorbance slope was recorded at $652 \mathrm{~nm}$ for $2 \mathrm{~min}$ [12].

\subsubsection{Catalase mimicking activity}

$\mathrm{H}_{2} \mathrm{O}_{2}$ decomposition by BSA-MnO $\mathrm{M}_{2}$ was studied using a fluorescent probe i.e. terephthalic acid. It reacts with hydroxyl radical to form a highly fluorescent compound, 2-hydroxyterephthalic acid. $10 \mathrm{mM} \mathrm{H}_{2} \mathrm{O}_{2}$ with $0.5 \mathrm{mM}$ terephthalic acid and different concentration of nanoparticles (final concentration in reaction volume 25,50 , $100,150,200,250,300 \mu \mathrm{g} / \mathrm{mL}$ ) were added to $100 \mathrm{mM}$ sodium acetate buffer $(\mathrm{pH}=5.0)$ and incubated in UV light $(365 \mathrm{~nm}$ ) for $20 \mathrm{~min}$. The solution was then centrifuged and fluorescence was measured using fluorescence spectrophotometer.

\subsection{Determination of enzyme activity}

Enzyme activity is a measure of catalytic ability and is calculated by estimation of decrease in substrate concentration or increase in product concentration after a defined time period [30]. Alternatively, enzyme activity refers to moles of product formed per unit time that is equivalent to rate $\times$ reaction volume. Moles of product formed was calculated using Beer Lambert's law $(C=A / \mathcal{E} L)$ for each concentration of NP used. $\mathcal{E}$ was taken as $3.9 \times 10^{4} \mathrm{M}^{-1} \mathrm{~cm}^{-1}$ for TMB product [31] and $16,700 \mathrm{M}^{-1} \mathrm{~cm}^{-1}$ for OPD product [32]. SOD activity was measured as "unit SOD". As One unit SOD is the amount of SOD required to cause $50 \%$ inhibition of NBT photoreduction rate, it was calculated as $(1 / 50) * \%$ inhibition [33].

\subsection{In vitro toxicity analysis of $\mathrm{BSA}-\mathrm{MnO}_{2}$ nanoparticles}

\subsubsection{Cell culture}

Human embryonic kidney (HEK 293) cell line was used for the study, which was procured from National Centre for Cell Science, Department of Biotechnology, Pune, India. For the cell culture, RPMI-1640 medium supplemented with 10\% (v/v) Fetal bovine serum (FBS), antibiotics (streptomycin $10 \mu \mathrm{g} / \mathrm{mL}$, penicillin $100 \mathrm{U} / \mathrm{mL}$ ) was used. 


\subsubsection{Cytotoxicity (MTT) assay}

BSA-MnO $\mathrm{MPs}_{2}$ was tested for any potential toxicity towards the HEK 293 cell lines. In brief, HEK 293 were seeded at cell density of $5 \times 10^{3}$ cells/well in 96 well plate and incubated at $37^{\circ} \mathrm{C}$ and $5 \% \mathrm{CO}_{2}$. On adherence of cells to the plate, nanoparticles were treated at varying concentration $(50,100,200$ and $400 \mu \mathrm{g} / \mathrm{mL})$ for 24,48 and $72 \mathrm{~h}$ respectively. After completion of respective time periods, $30 \mu \mathrm{L}$ of $1 \mathrm{mg} / \mathrm{mL}$ 3-(4,5-dimethylthiazol-2-yl)-2,5-diphenyl tetrazolium bromide (MTT) and $70 \mu \mathrm{L}$ fresh media was added to the well and incubated for $4 \mathrm{~h}$. The media was removed and replenished with $100 \mu \mathrm{L}$ Dimethyl Sulfoxide (DMSO). Absorbance was recorded in BIORAD ELISA plate reader at $570 \mathrm{~nm}$. Percentage cell viability was determined using the formula in Eq. 2.

$\%$ Cell Viability $=\frac{\text { Mean Absorbance }(\text { Treated Sample })}{\text { Mean Absorbance }(\text { Control Sample })} \times 100$.

\subsubsection{Electron microscopic analysis of treated HEK 293 cells}

To ascertain the internalization and subcellular localization of NPs, treated cells were subjected to TEM analysis. For this, cells were treated with $100 \mu \mathrm{g} / \mathrm{mL}$ of $\mathrm{BSA}-\mathrm{MnO}_{2}$ NPs and incubated for $24 \mathrm{~h}$. On completion of treatment period, cells were trypsinized, fixed with $2.5 \%$ glutaraldehyde for $30 \mathrm{~min}$, post-fixed using 1\% osmic acid and 0.1 M PBS was added. Cells were thereafter dehydrated in ethanol and were embedded in Epon 812 and sections were done using Ultramicrotom (Leica Ultracut-UCT) and visualized under on JEOL-JEM-2100F transmission electron microscope after staining with uranyl acetate.

\section{Result and discussion}

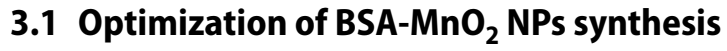

The BSA-MnO ${ }_{2}$ NPs synthesized in the present study involve oxidation of $\mathrm{Mn}^{2+}$ ions and BSA was used as the template for reaction [12]. Formation of NPs was inferred from the change in colour of reaction mixture from colourless to brownish orange color on addition of $\mathrm{NaOH}$ to the solution. UV-visible absorption spectra showed peaks at 280 and $335 \mathrm{~nm}$ corresponding to BSA and $\mathrm{MnO}_{2} \mathrm{NPs}$ respectively, confirming the formation of $\mathrm{BSA}-\mathrm{MnO}_{2} \mathrm{NPs}$ (Fig. 1a). Insert shows a magnified image showing the peak at $335 \mathrm{~nm}$ [34]. In the absence of $\mathrm{NaOH}$, no NP formation was observed which signifies the requirement of an alkaline $\mathrm{pH}$ for synthesis of $\mathrm{BSA}-\mathrm{MnO}_{2} \mathrm{NPs}$.

For optimization studies, we used three $\mathrm{Mn}$ precursor salts, among which NPs synthesized using $\mathrm{MnSO}_{4}$ showed maximum intensity with a distinct SPR peak. $\mathrm{MnSO}_{4}$ was therefore chosen as the optimized salt for synthesis of NPs. Additionally, we varied the initial concentration of BSA to optimize the size and shape of synthesized NPs. Figure $1 \mathrm{~b}$ reflects that variation of initial BSA concentration plays an integral role in the corresponding size and shape of NPs. BSA-MnO ${ }_{2}$ NPs synthesized using $7.5 \mathrm{mg} / \mathrm{mL}$ BSA showed maximum intensity in UV-visible absorption spectra. Larger sized particles with irregular morphology were formed at 2.5, 5 and $10 \mathrm{mg} / \mathrm{mL}$ BSA concentrations while monodispersed and spherical NPs were synthesized at $7.5 \mathrm{mg} / \mathrm{mL}$ BSA concentration. This was evident from the TEM micrographs shown in Fig. 2. The initial studies thus signify that the functional groups of BSA assist in the reduction and subsequent stabilization of formed $\mathrm{MnO}_{2}$ NPs which was also confirmed from FTIR analysis. Amino acids moieties present in BSA also show a strong interaction affinity to $\mathrm{Mn}^{2+}$ ions. The present synthesis process is an example of protein-NP interaction, depicting the importance of primary, secondary and tertiary protein structure in NP formation [12].
Fig. 1 a UV-visible spectra of $\mathrm{BSA}-\mathrm{MnO}_{2}$ nanoparticles synthesized from different manganese salts, $\mathbf{b}$ optical densities of nanoparticles synthesized with $2.5,5,7.5$ and $10 \mathrm{mg} / \mathrm{mL}$ BSA at $335 \mathrm{~nm}$
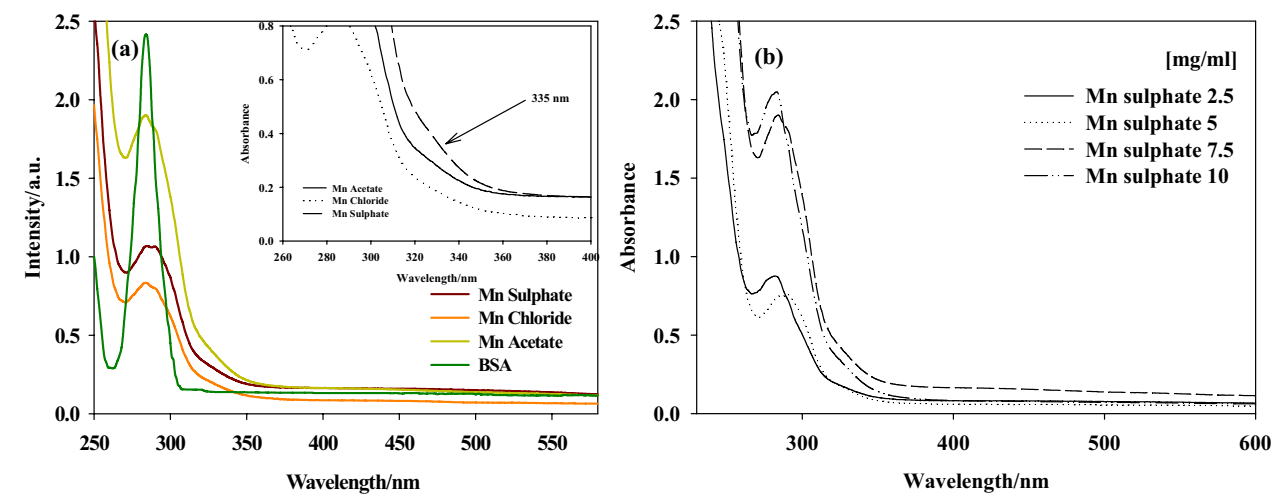
Fig. 2 TEM images of BSA$\mathrm{MnO}_{2} \mathrm{NPs}$ synthesized at varying concentration of $\mathrm{BSA}$ a $2.5 \mathrm{mg} / \mathrm{mL}$, b $5 \mathrm{mg} / \mathrm{mL}$, c $7.5 \mathrm{mg} / \mathrm{mL}, \mathbf{d} 10 \mathrm{mg} / \mathrm{mL}$
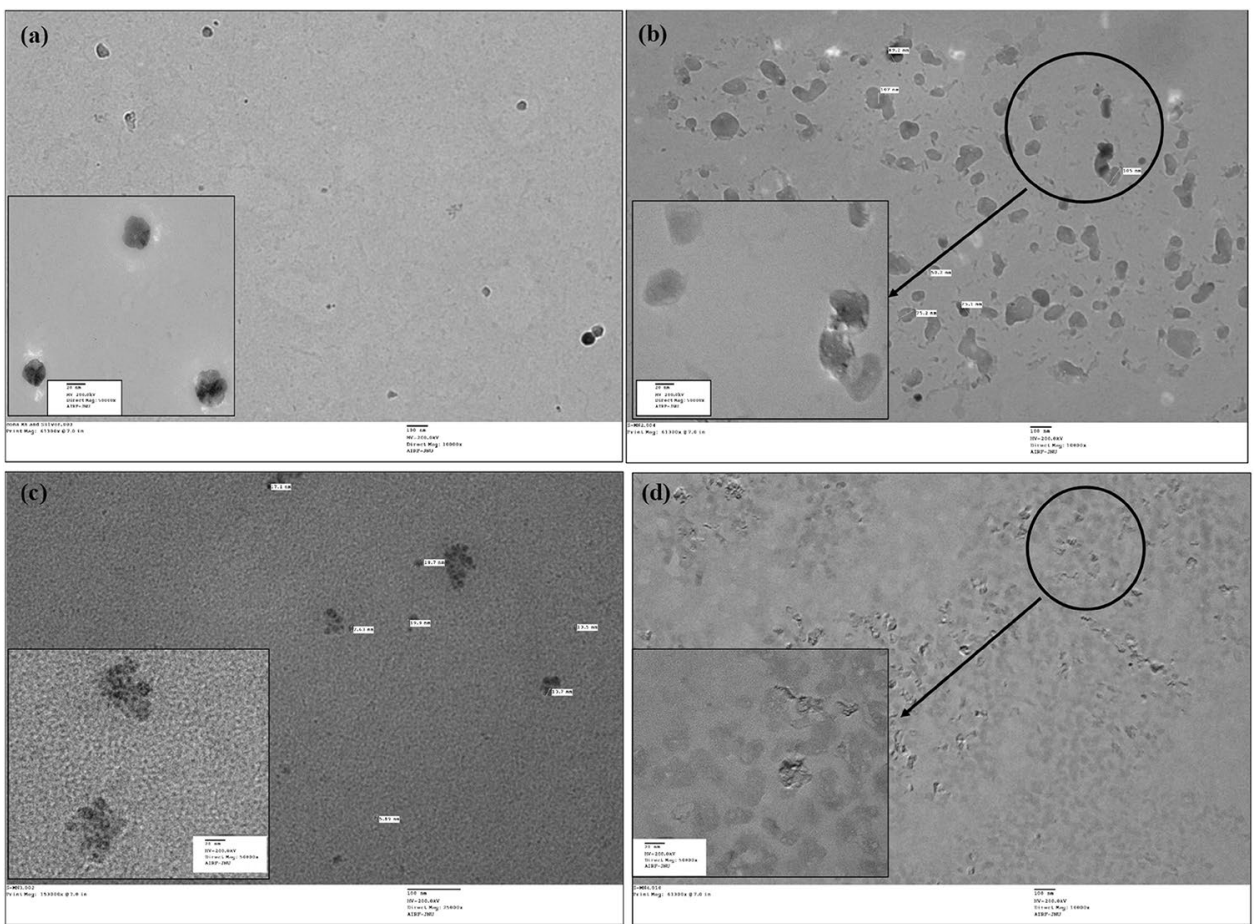

\subsection{Characterization of synthesized $\mathrm{BSA}-\mathrm{MnO}_{2}$ nanoparticles}

TEM images suggest the formation of monodispersed and homogenous NPs in the range of $4-20 \mathrm{~nm}$ with most of the particles in the size range of 10-12 nm (Fig. 2c). FTIR analysis was performed to determine the nature and purity of synthesized $\mathrm{BSA}-\mathrm{MnO}_{2} \mathrm{NPs}$
(Fig. 3). The presence of a small peak at $1000 \mathrm{~cm}^{-1}$ corresponds to $-\mathrm{S}=\mathrm{O}$ bond which might appear due to the sulphate salt used in synthesis process [35]. BSA- $\mathrm{MnO}_{2}$ NPs show peak at $2927 \mathrm{~cm}^{-1}$ and $1400 \mathrm{~cm}^{-1}$ which represents the $-\mathrm{OH}$ stretching band and appear because of the use of $\mathrm{NaOH}$ in the synthesis process. $\mathrm{Mn}-\mathrm{O}$ vibration is attributed to the presence of small peak at 890 and $782 \mathrm{~cm}^{-1}$ suggesting the a-MnO${ }_{2}$ conformation of
Fig. 3 Graph showing the FTIR spectra of BSA and BSA-MnO nanoparticles

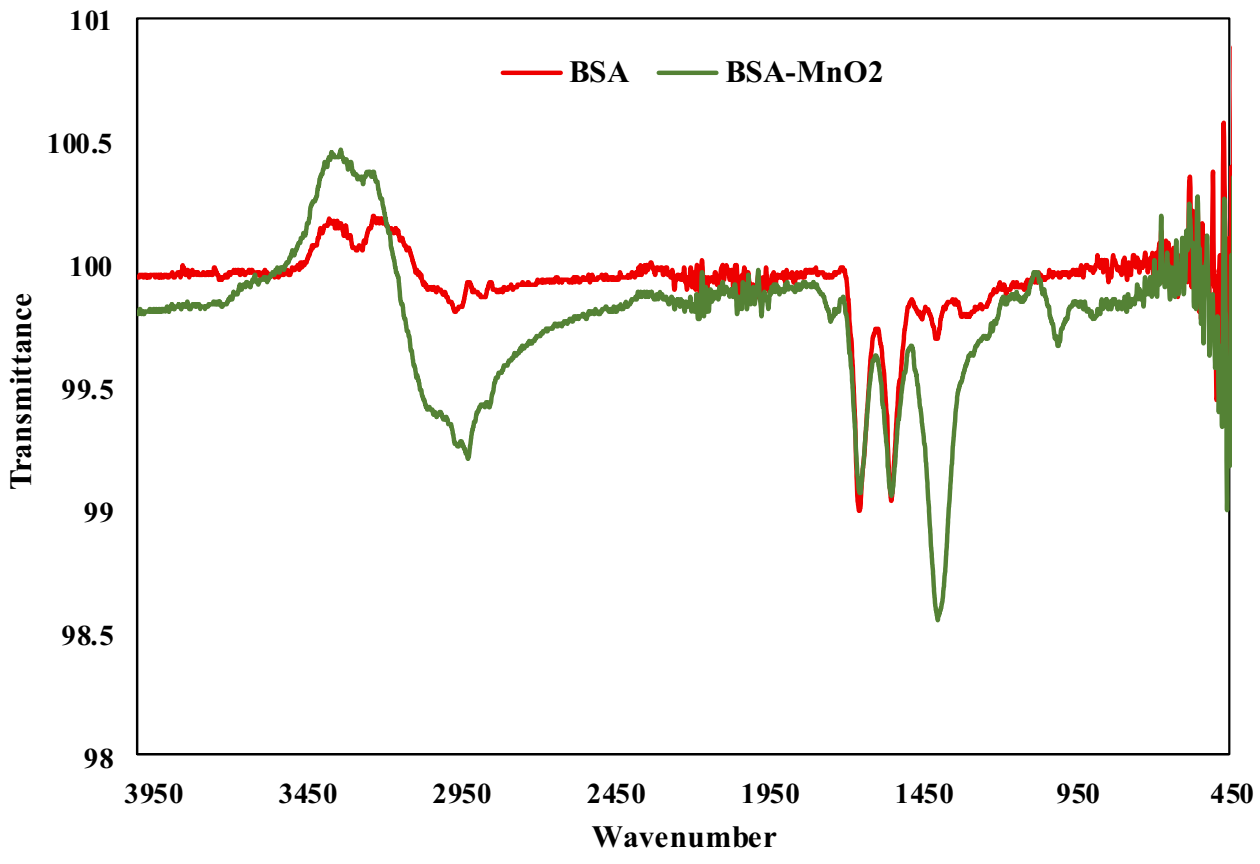

SN Applied Sciences 
NPs [36]. The additional peaks at 1650 and $1548 \mathrm{~cm}^{-1}$ is contributed from $\mathrm{C}=\mathrm{O}$ vibrations which corresponds to BSA-MnO $\mathrm{NPs}_{2}$ synthesized by Si et al. [37]. The FTIR spectra thus further confirm the formation of stabilized $\mathrm{BSA}-\mathrm{MnO}_{2} \mathrm{NPs}$.

Scanning electron microscopy analysis suggested the crystalline nature of NPs. However, the particles showed aggregated surface morphology which may be due to thin film formation prior to SEM analysis (Fig. 4a). Scanning Electron Microscope-Energy Dispersive X-ray spectroscopy (SEM-EDX) analysis further confirms the formation of BSA-MnO $\mathrm{NPs}_{2}$ evident by the appearance of strong signals for $\mathrm{Mn}$ and $\mathrm{O}$ (Fig. 4b). Elemental analysis showed the presence of manganese (25.4\%), carbon (25.38\%), nitrogen (6.99\%), copper $(0.48 \%)$ and oxygen (41.74\%). The presence of carbon is because of the use of carbon tape in SEM-EDX analysis. Presence of nitrogen in the BSA-MnO 2 NPs was in accordance with Liu et al. [12]. DLS analysis signified that the average hydrodynamic radius $\left(R_{h}\right)$ of the particles to be $79.8 \mathrm{~nm}$ and the zeta potential was observed to be in the range of -40 to $-60 \mathrm{mV}$ (Fig. $4 \mathrm{c}$ and d), which suggests the aqueous stability of formed $\mathrm{BSA}-\mathrm{MnO}_{2} \mathrm{NPs}$.

\subsection{Analysis of anti-oxidant property of $\mathrm{BSA}-\mathrm{MnO}_{2}$ NPs}

Antioxidant enzymes exert a protective role, preventing the damages by free radicals generated by various biochemical reactions in the body. Humans possess an endogenous antioxidant system comprising of free radical scavenging enzymes such as catalase, superoxide dismutase, glutathione reductase and peroxidase [3]. Previous studies suggest that inorganic nanoparticles such as cerium oxide and manganese dioxide scavenge free radicals and prevent the in vitro system from oxidative damage [12, 38]. These nanoparticles, form a novel group of enzymes called nanozymes. Nanozymes can either be antioxidants or pro-oxidants depending on their ability to scavenge or generate free radicals respectively. In order to divulge the potential role of the synthesized $\mathrm{BSA}-\mathrm{MnO}_{2} \mathrm{NPs}$, we performed a series of antioxidant assays as described below.

On assaying for peroxidase activity, the particles were observed to show a positive peroxidase activity evident by oxidation of $o$-phenylenediamine substrate. A change in colour of the assay mixture to yellow, along with an increase in optical absorbance of substrate was found with increasing BSA-MnO ${ }_{2} \mathrm{NPs}$ concentration. The high efficiency of peroxidase like activity was depicted by
Fig. 4 a SEM micrograph of as-synthesized BSA $\mathrm{MnO}_{2}$ nanoparticles, b EDX analysis of particles showing the presence of $\mathrm{Mn}$ and $\mathrm{O}$ peaks conforming the formation of $\mathrm{MnO}_{2}$ particles, c DLS analysis showing the hydrodynamic radius of particles, $\mathbf{d}$ Zeta potential histogram of the particles
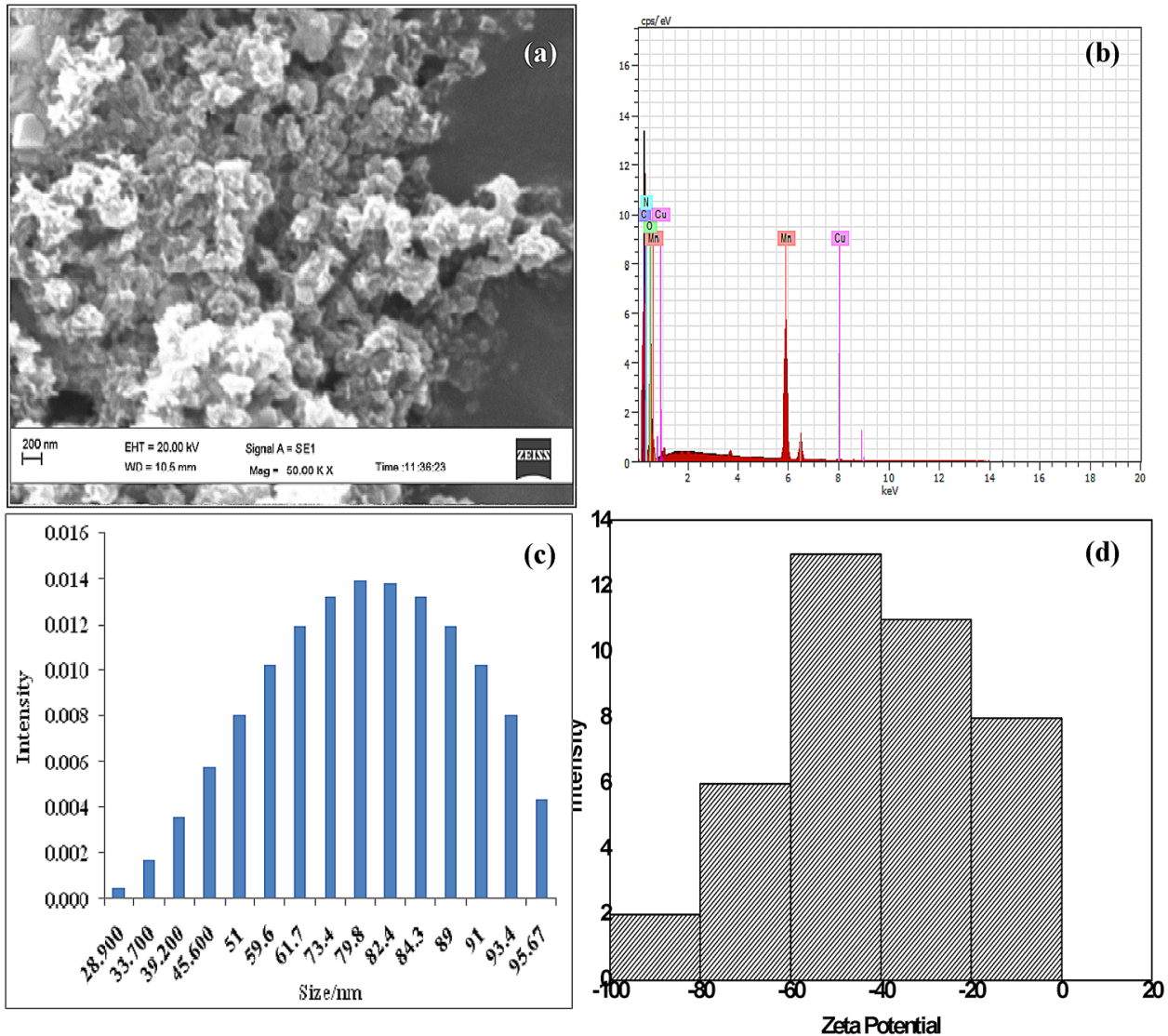
change in colour within a minute of adding NPs to the assay mixture, the intensity of which was found to increase with concentration of NPs. The control set did not show any change in colour nor was there any change in the optical absorbance (Fig. 5a). Gao and et al. showed that iron nanoparticles exhibit peroxidase like activity, with smaller size exhibiting higher activity than the bigger ones. Iron oxide NPs of different sizes (30,50 and $300 \mathrm{~nm}$ ) were first reported for peroxidase activity [11]. Similarly, $\mathrm{V}_{2} \mathrm{O}_{5}$ nanowires have been recently reported to show an exceptional peroxidase activity with increasing particle concentration [39]. Other nanomaterials like nanostructured layered double hydroxide (LDH), ruthenium and gold nanoparticles have also been reported to show peroxidase-like activity [40-42].

Likewise, the NPs were found to show oxidase activity observed by change in colour of the reaction mixture on addition of NPs, within $30 \mathrm{~s}$. The intensity of blue colour was found to increase with NPs concentration as can be seen in Fig. 5b. Moreover, the oxidase substrate TMB showed increase in absorbance with increase in concentration of $\mathrm{BSA}-\mathrm{MnO}_{2}$ nanoparticle (Fig. 5b). The results confirmed that the synthesized nanoparticles have oxidase-like activity. These results are in accordance with Liu and colleagues who reported the oxidase like activity of $\mathrm{MnO}_{2} \mathrm{NPs}$ [12]. In yet another study, oxidase like activity of $\mathrm{MnO}_{2}$ nanowires was used for developing immunoassay platform for sulfate reducing bacteria. The resultant nanowire showed superior detection performance compared to HRP-based enzyme-linked immunosorbent assay (ELISA) [43]. Several other nanomaterials have been shown to mimic oxidase enzyme-like activity $[41,44]$. Nanomaterials like gold nanoparticles, gold platinum nanostructure and Fe-Pt alloy nanoparticles have been shown to exhibit increasing oxidase activity with increase in concentration [45-47]. Variation in size, shape and stabilizing substrate is known to affect the property of NPs. Studies signify that dextran coated cerium NPs have oxidase mimicking property while naked cerium NPs synthesized by a similar method lack oxidase activity, however showed SOD and catalase like property $[23,48]$.

Further, the $\mathrm{BSA}-\mathrm{MnO}_{2} \mathrm{NPs}$ showed catalase like activity which is in accordance with the study reported by Liu and colleagues [12]. This shows that $\mathrm{MnO}_{2} \mathrm{NPs}$ possess the ability of catalysing the decomposition of $\mathrm{H}_{2} \mathrm{O}_{2}$ with the formation of water and oxygen and thus reduce the $\mathrm{OH}$ radical in a concentration dependent manner. For this, terephthalic acid was used as the fluorescence probe that reacts with $\mathrm{OH}^{-}$ions to form highly fluorescent 2-hydroxyterephthalic acid. A gradual decrease in fluorescence intensity of 2-hydroxyterephthalic acid was found with increasing NPs concentration (Fig. 6) signifying the ability of the $\mathrm{BSA}-\mathrm{MnO}_{2} \mathrm{NPs}$, to reduce $\mathrm{OH}^{-}$production. Reports show that several types of nanoparticles exhibit catalase like activities. Concentration dependent increase in the catalase mimicking activity of cerium oxide [49] and manganese dioxide [12] have been reported. Other nanoparticles such as gold nanoparticles (AuNPs), iron oxides, and cobalt oxide nanoparticles also show catalase like activity [50-52].

Besides catalase, the BSA-MnO 2 NPs showed SOD like activity as well. As can be seen in Fig. 7, the percent inhibition of NBT reduction was enhanced with increase in NP concentration. This suggests that the NPs could scavenge superoxide radicals in a concentration dependent manner, so that the radicals were unable to reduce NBT to
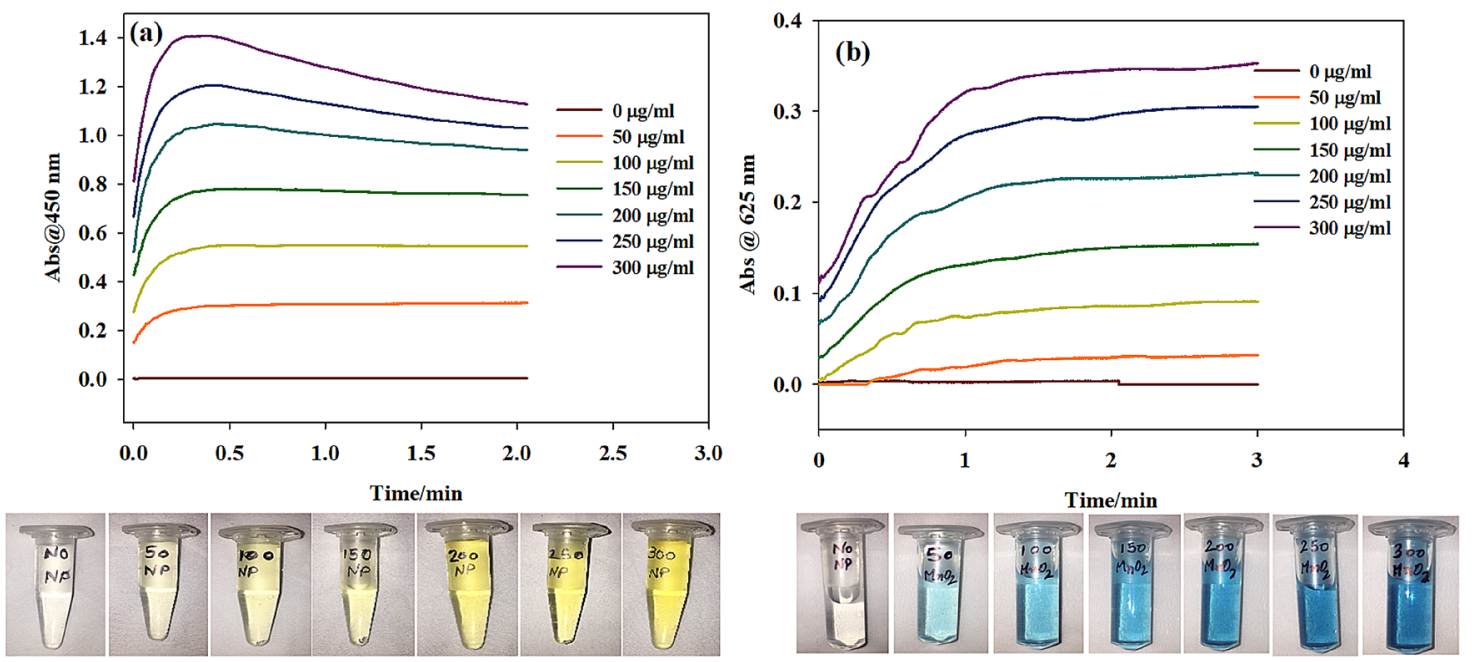

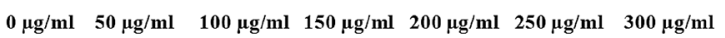

Fig. 5 UV-visible absorption spectra showing a peroxidase and $\mathbf{b}$ oxidase like-activity of BSA-MnO $\mathrm{NPs}_{2}$ 


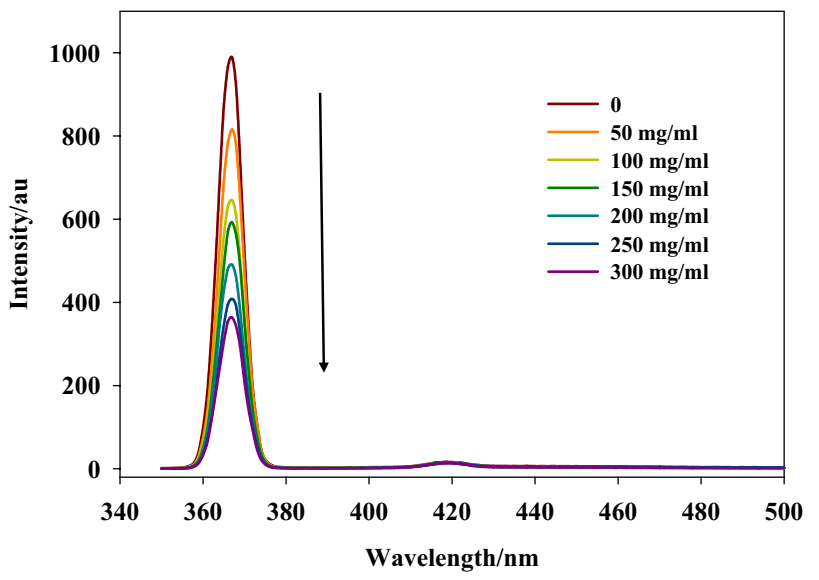

Fig. 6 Catalase like activity of $\mathrm{BSA}-\mathrm{MnO}_{2} \mathrm{NPs}$ evident by decrease in fluorescence intensity with increasing NPs concentration

formazan. The SOD mimicking activity of the synthesized nanoparticles is in accordance with the enzyme mimicking activities of $\mathrm{MnO}_{2} \mathrm{NPs}$ discussed above. Recent study reported that nanoceria mimics SOD [53]. The increase in SOD activity with increase in concentration of nanoceria has been reported [54]. Apart from manganese and cerium nanoparticle, apo-ferritin encapsulated platinum nanoparticles (PtNPs) have been shown to mimic SOD [55].

Furthermore, the enzyme activity was determined for SOD, oxidase and peroxidase by using Beer-Lambert's law as described in material section. The results have been summarized in Table 1. However, we were not able to calculate catalase activity as the assay uses the fluorescent probe, terephthalic acid which on binding with hydroxide ions generate fluorescence. Since, Beer-Lambert's law can't be used for fluorescence studies, we were not able to determine the enzyme activity. Decrease in fluorescence intensity was used as an estimate for the same.

\subsection{In-vitro cytotoxicity profiling of $\mathrm{BSA}-\mathrm{MnO}_{2} \mathrm{NPs}$}

The synthesized NPs show antioxidant activities as has been described in the previous sections. In vitro antioxidant property of NPs, instigated us to analyse the cytoprotective role of the synthesized NPs on HEK 293 cells, which is a normal human embryonic kidney cell line. MTT assay was used to analyse the cell proliferative activity,

Table 1 Peroxidase, oxidase and SOD enzyme like activity of BSA$\mathrm{MnO}_{2} \mathrm{NPs}$

\begin{tabular}{llll}
\hline $\begin{array}{l}\mathrm{BSA}-\mathrm{MnO}_{2} \mathrm{NP} \\
(\mu \mathrm{g} / \mathrm{ml})\end{array}$ & $\begin{array}{l}\text { Peroxidase } \\
\text { activity }(\mu \mathrm{mol} \\
\text { product } / \mathrm{min})\end{array}$ & $\begin{array}{l}\text { Oxidase activity } \\
(\mu \mathrm{mol} \text { product/ } \\
\text { min) }\end{array}$ & $\begin{array}{l}\text { SOD activity } \\
\text { (unit SOD) }\end{array}$ \\
\hline 50 & 0.005 & 0.188 & 0.048 \\
100 & 0.023 & 0.339 & 0.104 \\
150 & 0.076 & 0.497 & 0.309 \\
200 & 0.142 & 0.680 & 0.397 \\
250 & 0.202 & 0.792 & 0.565 \\
300 & 0.237 & 0.962 & 0.705 \\
\hline
\end{tabular}

Fig. 7 Graph showing an increase in percentage inhibition of NBT reduction with increasing NPs concentration suggesting SOD mimicking property

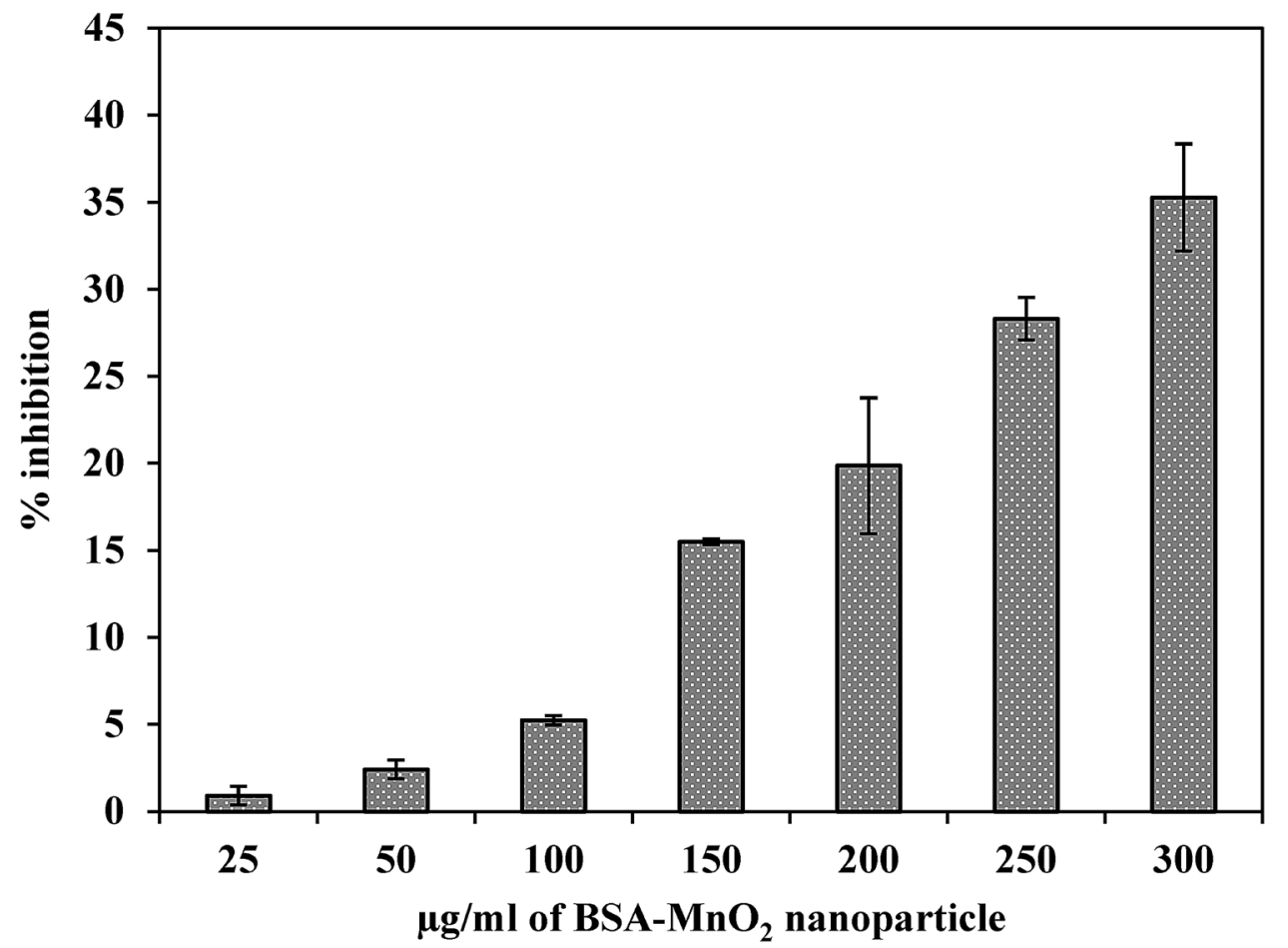


which suggests the $\mathrm{BSA}-\mathrm{MnO}_{2} \mathrm{NPs}$ to be potentially nontoxic. Cellular response to increasing concentration of $\mathrm{MnO}_{2} \mathrm{NPs}$ is shown in Fig. 8. Results showed no significant cell death within $24 \mathrm{~h}$ of treatment in doses from 50 to $150 \mu \mathrm{g} / \mathrm{mL}$ whereas a significant cell death was noticed on cells treated with $200 \mu \mathrm{g} / \mathrm{mL}$. Upon $48 \mathrm{~h}$ of treatment, significant decrease in percent viability was observed at 150 and $200 \mu \mathrm{g} / \mathrm{mL}$ concentration. After $72 \mathrm{~h}$, percentage viability of cells increased significantly at $50 \mu \mathrm{g} / \mathrm{mL}$, while decreased significantly at higher doses. $66.5 \%$ cell viability was observed for the maximum concentration of NPs studied i.e. $200 \mu \mathrm{g} / \mathrm{mL}$. The MTT assay thus suggests a significant higher concentration of $\mathrm{MnO}_{2} \mathrm{NPs}$ induced toxicity after exposure time of $72 \mathrm{~h}$. Thus, despite the nanoparticle acting as an antioxidant at lower doses, in higher doses it caused the generation of ROS rather than quenching it and thus could significantly decrease $\%$ viability of cells. This may be due to oxidase mimicking activity of nanoparticles as the enzyme do not require hydrogen peroxide, rather it can produce $\mathrm{H}_{2} \mathrm{O}_{2}$ (or superoxide in some cases) [3].

Electron micrograph was analysed to confirm the internalization of the NPs into the cells. The $\mathrm{MnO}_{2}$ particles

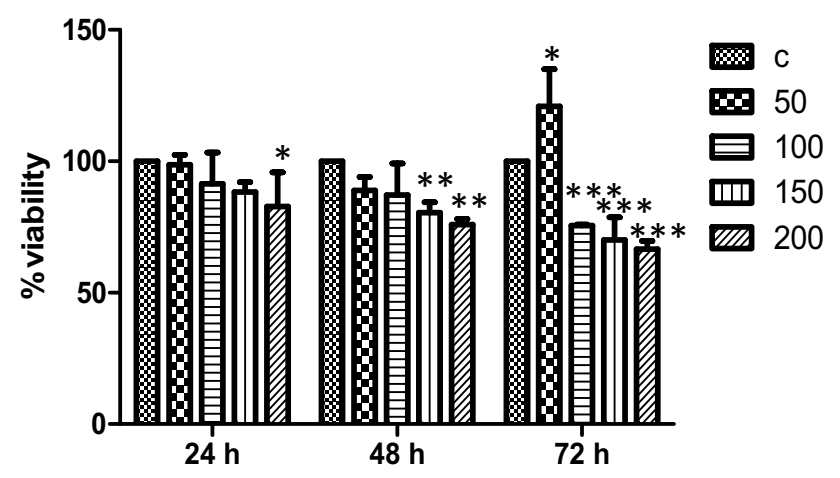

Fig. 8 Percentage viability of HEK 293 cells upon treatment with synthesized nanoparticles $\left({ }^{*} p<0.05\right.$ significant; ${ }^{* *} p<0.01$ very significant; ${ }^{* * *} p<0.001$ highly significant) were entrapped by the cells (Fig. 9). A comparative analysis of untreated and treated cells suggest no significant change in cell morphology or nuclear damage. This signifies that though the $\mathrm{MnO}_{2} \mathrm{NPs}$ were taken up by the cells but were potentially non-toxic. Figure $9 b$ and $c$ show the treated cells wherein the nanoparticles are observed to be localized in the cell interior. We observed that the NPs were internalized in the lysosomes and no cellular damage was observed. Non-toxicity of $\mathrm{MnO}_{2}$ cells towards HEK 293 cell lines might be due to the acidic nature of lysosome. As lysosomal vesicles are known to be acidic with $\mathrm{pH}$ of 4 , that can lead to degradation of $\mathrm{BSA}-\mathrm{MnO}_{2} \mathrm{NPs}$ [56], resulting in the release of free $\mathrm{Mn}^{2+}$ ions. $\mathrm{Mn}^{2+}$ are known to possess a very high affinity towards $\mathrm{H}_{2} \mathrm{O}_{2}$ and $\mathrm{O}_{2}{ }^{-}$free radicals. Hence, the $\mathrm{Mn}^{2+}$ ions can bind to them thereby preventing excess ROS level and thus have a protective effect [57, 58]. This is in accordance with the antioxidant property of as-synthesized BSA-MnO ${ }_{2} \mathrm{NPs}$ and thus explains the nontoxic nature towards HEK 293 cell lines at lower doses.

The results signified that the synthesized $\mathrm{BSA}-\mathrm{MnO}_{2}$ NPs exhibit both pro and antioxidant activity as they were found positive for oxidase, peroxidase, catalase like activity respectively. These results were in accordance with Liu et al. [12]. In addition, we also found a positive SOD mimicking activity by the synthesized NPs. SOD enzyme activity suggested an increment in SOD activity with increasing concentration of NPs. This confirmed the dual-property of antioxidant and pro-oxidant role of synthesized particles, which was further elucidated by in vitro assay (MTT and TEM) on normal HEK 293 cells. The dosedependent invitro response of NPs, suggest that by simple modulation of the $\mathrm{BSA}-\mathrm{MnO}_{2} \mathrm{NPs}$ concentration, it may be used as therapeutic and diagnosis substrate. Graphical illustration in Scheme 1 represents the basic reaction of pro- and antioxidants catalysed by $\mathrm{BSA}-\mathrm{MnO}_{2} \mathrm{NPs}$ and the generalized reaction product formed. NPs of iron and copper were known to have pro-oxidant activity wherein they had the ability to generate free radicals in the living body and lead to oxidative stress. Various toxicological
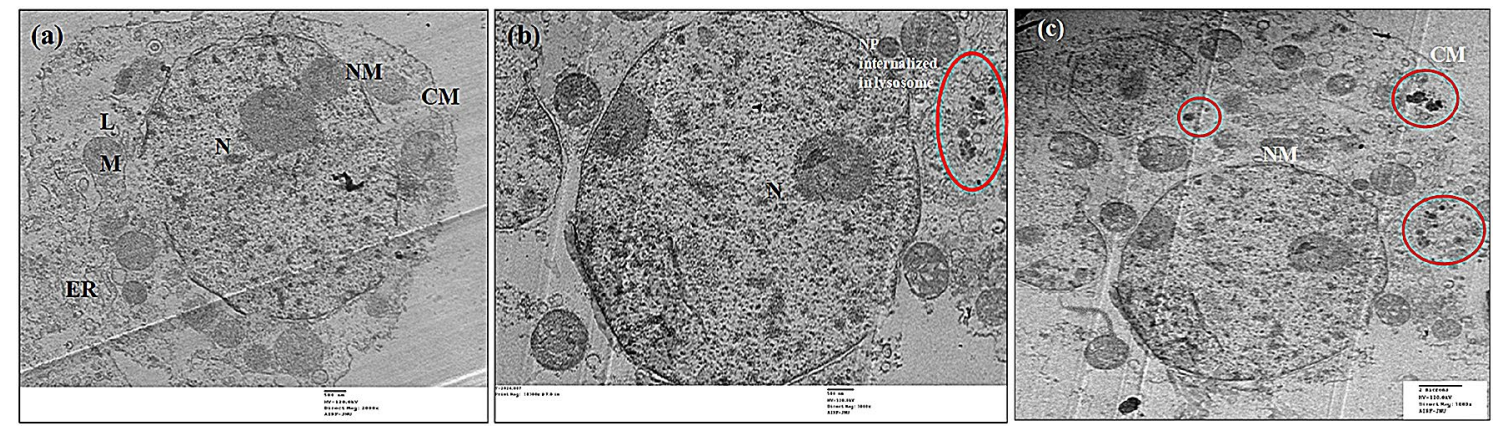

Fig. 9 TEM micrograph of a Control HEK 293 cells (L-Lysosome, M-Mitochondria, ER-Endoplasmic reticulum, N-Nucleus, NM-Nuclear membrane, CM-Cell membrane) b, c nanoparticle treated cells. The internalized particles have been depicted by red circle in the image 


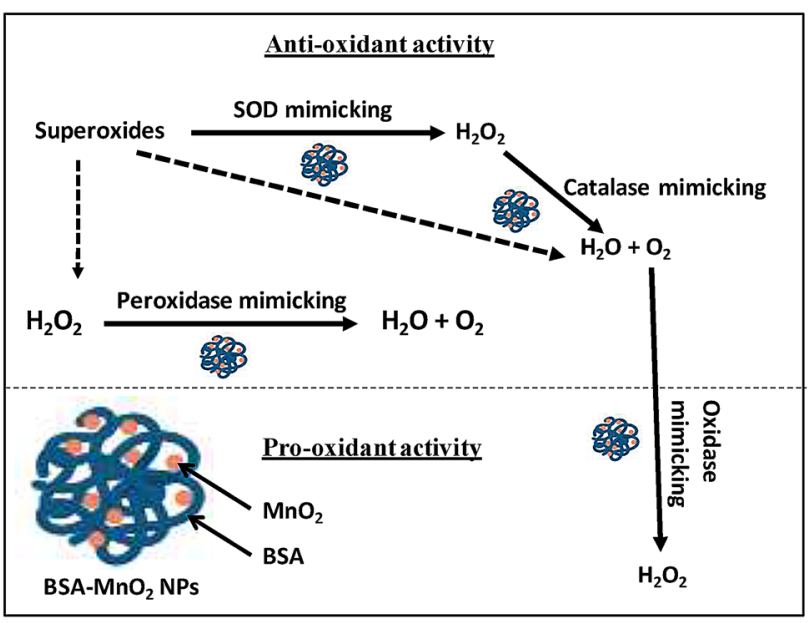

Scheme 1 Graphical representation of the catalysed reactions and the generalized end-products formed

studies involving Mn NPs report it to be non-toxic nature at lower doses but showed toxicity at higher doses, which is in accordance with the in vitro experiments observed in the present study. $\mathrm{MnO}_{2} \mathrm{NPs}$ treated on human neuronal cells SH-SY5Y showed decline in mitochondrial membrane potential, increase in lipid peroxidation, SOD, CAT and decrease in glutathione in dose and time dependent manner. An increase in caspase 3 activity, DNA strand break (comet assay), and apoptotic cells was observed at $60 \mu \mathrm{g} / \mathrm{mL}$ of the nanoparticles at $48 \mathrm{~h}$ [59]. The effect of manganese oxide nanoparticle in PC-12 cells of $24 \mathrm{~h}$ treatment did not significantly change the cell morphology whereas silver nanoparticle of the same concentration produced cell shrinkage with irregular membrane borders. Mitochondrial reduction activity in the cells was of moderate toxicity as compared to the silver nanoparticle of similar dose [60]. However, there was a significant increase in ROS with increase in dose. But, these studies are limited to in vitro conditions and require in vivo investigation before coming to any conclusive evidence on toxicity of $\mathrm{MnO}_{2}$ NPs. In vivo oral treatment of Wistar rats with Mn NPs for 28 days showed DNA damage in leukocytes, micronuclei and chromosomal aberration in bone marrow cells, acetylcholinesterase inhibition in blood and significant alterations in biochemical enzymes at higher doses (300 and $1000 \mathrm{mg} / \mathrm{kg} \mathrm{bw}$ ). However, there was no or minimal toxicity at low dose (30 mg/kg bw) [61]. Daily intraperitoneal administration of $\mathrm{MnO}_{2} \mathrm{NPs}$ ( $10 \mathrm{mg} / \mathrm{kg}$ bw) for 50 days to $\mathrm{BALB} / \mathrm{C}$ mice significantly reduced liver and kidney functions and elevated glucose and bilirubin serum levels [62] $\mathrm{MnO}_{2} \mathrm{NPs}$ also showed reproductive toxicity at $100 \mathrm{mg} / \mathrm{kg}$ on subcutaneous administration in male rats once a week for 4 weeks [63].

On the other hand, $\mathrm{MnO}_{2} \mathrm{NPs}$ have shown to work as nanozymes and improve conditions as discussed previously in the introduction section. It can thus be suggested that size, morphology and surface functionalization has an essential role in devising the subsequent property and nature of NPs. Optimizing the dose and fabricating $\mathrm{MnO}_{2}$ NPs with appropriate stabilizing agent, can result in generation of NPs with high anti-oxidant activity which can be used in biomedical applications after determination of their in vivo toxicity.

\section{Conclusion}

The $\mathrm{BSA}-\mathrm{MnO}_{2} \mathrm{NPs}$ synthesized were in the size range of 10-12 $\mathrm{nm}$ and of $\mathrm{a}-\mathrm{MnO}_{2}$ conformation. A comprehensive study signified that the $\mathrm{MnO}_{2} \mathrm{NPs}$ exhibited antioxidant (SOD, Catalase, Peroxidase) activity along with oxidase activity. SOD mimicking activity of the NPs to inhibit the NBT reduction to formazan enhanced with increasing NP concentration. The NPs also mimicked catalase by preventing $\mathrm{OH}^{-}$production from $\mathrm{H}_{2} \mathrm{O}_{2}$. Furthermore, oxidase and peroxidase mimicking activity increased with concentration of NPs, which was also evident from the color change of their respective chromogenic substrates. Oxidase mimicking activity of the synthesized NPs signifies their pro-oxidant ability which makes the NPs toxic at high dose $(200 \mu \mathrm{g} / \mathrm{mL})$ in cell proliferation assay. However the NPs were able to increase the cell viability at a low dose $(50 \mu \mathrm{g} / \mathrm{mL})$. The results confirms that BSA template $\mathrm{MnO}_{2}$ NPs mimic oxidase, peroxidase and catalase enzymes. Further, SOD mimicking property and in vitro assay of NP in HEK 293 cells, revealed the non-toxic concentration and toxicity at higher concentration. Moreover, the NP showed in vitro anti-oxidative nature at optimum dose. This allows optimization of the doses for subsequent in-vivo experimentations. It can thus be concluded that though the nanoparticle is toxic at higher doses, at an optimum dose, it has enormous potential in biomedical application where it can act as antioxidant nanozymes to protect mammalian cells from oxidative stress. The results presented here insights into the promising therapeutic applications of NPs in inflammatory, ocular, neurodegenerative, gastrointestinal, autoimmune, renal, musculoskeletal, cardiovascular, pulmonary diseases and in tumours and cancers.

Acknowledgements The authors thank Advanced Instrument Research Facility (AIRF), Jawaharlal Nehru University, New Delhi for Analytical Characterization. SP is grateful to Council of Scientific and Industrial Research (CSIR) for providing fellowship (Sanction No. 09/263(1038)/2014-EMR-I) for performing the study. EP is grateful 
to Science and Engineering Board for fellowship under National Postdoctorate Scheme (Grant number PDF/2017/000024).

\section{Compliance with ethical standards}

Conflict of interest The authors declare here no conflict of interest.

\section{References}

1. Jeon WB, Bae KH, Byun SM (1998) Dimeric $\beta$-cyclodextrin-based supramolecular ligands and their copper(II) complexes as metalloenzyme models. J Inorg Biochem 71:163-169. https://doi. org/10.1016/S0162-0134(98)10049-1

2. Raynal M, Ballester P, Vidal-Ferran A, van Leeuwen PWNM (2014) Supramolecular catalysis. Part 2: artificial enzyme mimics. Chem Soc Rev 43:1734-1787. https://doi.org/10.1039/C3CS60037H

3. Singh S (2019) Nanomaterials exhibiting enzyme-like properties (nanozymes): current advances and future perspectives. Front Chem 7:46. https://doi.org/10.3389/fchem.2019.00046

4. Breslow R, Overman LE (1970) "Artificial enzyme" combining a metal catalytic group and a hydrophobic binding cavity. J Am Chem Soc 92:1075-1077. https://doi.org/10.1021/ja00707a062

5. Manea F, Houillon FB, Pasquato L, Scrimin P (2004) Nanozymes: gold-nanoparticle-based transphosphorylation catalysts. Angew Chemie Int Ed 43:6165-6169. https://doi.org/10.1002/ anie. 200460649

6. Wei $H$, Wang $E$ (2013) Nanomaterials with enzyme-like characteristics (nanozymes): next- generation artificial enzymes. Chem Soc Rev 42:6060. https://doi.org/10.1039/c3cs35486e

7. Priyadarshini E, Rawat K, Bohidar HB, Rajamani P (2019) Dualprobe (colorimetric and fluorometric) detection of ferritin using antibody-modified gold@carbon dot nanoconjugates. Microchim Acta 186:687. https://doi.org/10.1007/s00604-019-3802-1

8. Anand K, Tiloke C, Phulukdaree A et al (2016) Biosynthesis of palladium nanoparticles by using Moringa oleifera flower extract and their catalytic and biological properties. J Photochem Photobiol, B 165:87-95. https://doi.org/10.1016/j.jphotobiol .2016.09.039

9. Ali SS, Hardt Jl, Quick KL et al (2004) A biologically effective fullerene (C60) derivative with superoxide dismutase mimetic properties. Free Radic Biol Med 37:1191-1202. https://doi. org/10.1016/J.FREERADBIOMED.2004.07.002

10. Chen J, Patil S, Seal S, McGinnis JF (2006) Rare earth nanoparticles prevent retinal degeneration induced by intracellular peroxides. Nat Nanotechnol 1:142-150. https://doi.org/10.1038/ nnano.2006.91

11. Gao L, Zhuang J, Nie L et al (2007) Intrinsic peroxidase-like activity of ferromagnetic nanoparticles. Nat Nanotechnol 2:577-583. https://doi.org/10.1038/nnano.2007.260

12. Liu X, Wang $\mathrm{Q}$, Zhao $\mathrm{H}$ et al (2012) BSA-templated $\mathrm{MnO}_{2}$ nanoparticles as both peroxidase and oxidase mimics. Analyst 137:4552. https://doi.org/10.1039/c2an35700c

13. Zhao Z, Fan H, Zhou G et al (2014) Activatable fluorescence/MRI bimodal platform for tumor cell imaging via $\mathrm{MnO}_{2}$ nanosheetaptamer nanoprobe. J Am Chem Soc 136:11220-11223. https ://doi.org/10.1021/ja5029364

14. Fan $\mathrm{H}$, Yan G, Zhao Z et al (2016) A smart photosensitizer-manganese dioxide nanosystem for enhanced photodynamic therapy by reducing glutathione levels in cancer cells. Angew Chem Int Ed 55:5477-5482. https://doi.org/10.1002/anie.201510748

15. Chen $\mathrm{Q}$, Feng $\mathrm{L}$, Liu J et al (2016) Intelligent albumin- $\mathrm{MnO}_{2}$ Nanoparticles as $\mathrm{pH}-/ \mathrm{H}_{2} \mathrm{O}_{2}$ responsive dissociable nanocarriers to modulate tumor hypoxia for effective combination therapy. Adv Mater 28:7129-7136. https://doi.org/10.1002/ adma.201601902

16. Anand K, Rajamanikandan R, Selva Sharma A et al (2020) Human serum albumin interaction, in silico and anticancer evaluation of Pine-Gold nanoparticles. Process Biochem 89:98-109. https://doi.org/10.1016/j.procbio.2019.09.036

17. D'Autréaux B, Toledano MB (2007) ROS as signalling molecules: mechanisms that generate specificity in ROS homeostasis. Nat Rev Mol Cell Biol 8:813-824. https://doi.org/10.1038/nrm2256

18. Pisoschi AM, Pop A (2015) The role of antioxidants in the chemistry of oxidative stress: a review. Eur J Med Chem 97:5574. https://doi.org/10.1016/j.ejmech.2015.04.040

19. Baynes JW (1991) Role of oxidative stress in development of complications in diabetes. Diabetes 40:405-412. https://doi. org/10.2337/diab.40.4.405

20. Finkel T, Holbrook NJ (2000) Oxidants, oxidative stress and the biology of ageing. Nature 408:239-247. https://doi. org/10.1038/35041687

21. Lyras L, Cairns NJ, Jenner A et al (1997) An assessment of oxidative damage to proteins, lipids, and DNA in brain from patients with Alzheimer's disease. J Neurochem 68:20612069. https://doi.org/10.1046/j.1471-4159.1997.68052061.x

22. Singh N, Savanur MA, Srivastava $S$ et al (2017) A redox modulatory $\mathrm{Mn}_{3} \mathrm{O}_{4}$ nanozyme with multi-enzyme activity provides efficient cytoprotection to human cells in a Parkinson's disease model. Angew Chem Int Ed 56:14267-14271. https://doi. org/10.1002/anie.201708573

23. Asati A, Santra S, Kaittanis C et al (2009) Oxidase-like activity of polymer-coated cerium oxide nanoparticles. Angew Chem Int Ed 48:2308-2312. https://doi.org/10.1002/anie.200805279

24. Dong J, Song L, Yin J-J et al (2014) $\mathrm{CO}_{3} \mathrm{O}_{4}$ nanoparticles with multi-enzyme activities and their application in immunohistochemical assay. ACS Appl Mater Interfaces 6:1959-1970. https ://doi.org/10.1021/am405009f

25. Vernekar AA, Sinha D, Srivastava S et al (2014) An antioxidant nanozyme that uncovers the cytoprotective potential of vanadia nanowires. Nat Commun 5:5301. https://doi.org/10.1038/ ncomms6301

26. Singh N, Savanur MA, Srivastava S et al (2019) A manganese oxide nanozyme prevents the oxidative damage of biomolecules without affecting the endogenous antioxidant system. Nanoscale 11:3855-3863. https://doi.org/10.1039/C8NR0 9397K

27. Priyadarshini E, Rawat K (2017) Au@carbon dot nanoconjugates as a dual mode enzyme-free sensing platform for cholesterol. J Mater Chem B 5:5425-5432. https://doi.org/10.1039/C7TB0 $1345 \mathrm{~K}$

28. Beyer WF, Fridovich I (1987) Assaying for superoxide dismutase activity: some large consequences of minor changes in conditions. Anal Biochem 161:559-566. https://doi.org/10.1016/00032697(87)90489-1

29. Piacham T, Ayudhya CIN, Prachayasittikul V et al (2003) A polymer supported manganese catalyst useful as a superoxide dismutase mimic. Chem Commun (Camb) 11:1254-1255. https:// doi.org/10.1039/b301683h

30. Worsfold P, Townshend A, Poole CF, Miró M (2019) Encyclopedia of analytical science. Elsevier, Amsterdam

31. Aumiller WM Jr, Davis BW, Hatzakis E, Keating CD (2014) Interactions of macromolecular crowding agents and cosolutes with small-molecule substrates: effect on horseradish peroxidase activity with two different substrates. J Phys Chem B 118(36):10624-10632. https://doi.org/10.1021/jp506594f

32. Liu Y, Zhu G, Yang J, Yuan A, Shen X (2014) Peroxidase-like catalytic activity of $\mathrm{Ag}_{3} \mathrm{PO}_{4}$ nanocrystals prepared by a colloidal route. PLoS ONE 9(10):e109158. https://doi.org/10.1371/journ al.pone.0109158 
33. Assady M, Farahnak A, Golestani A, Esharghian MR (2011) Superoxide dismutase (SOD) enzyme activity assay in Fasciola spp. parasites and liver tissue extract. Iran J Parasitol 6(4):17-22

34. Hu D, Chen L, Qu Y et al (2018) Oxygen-generating hybrid polymeric nanoparticles with encapsulated doxorubicin and Chlorin e6 for trimodal imaging-guided combined chemo photodynamic therapy. Theranostics 8:1558-1574. https://doi. org/10.7150/thno.22989

35. Yang R, Wang Z, Dai L, Chen L (2005) Synthesis and characterization of single-crystalline nanorods of $a-\mathrm{MnO}_{2}$ and $\mathrm{p}-\mathrm{MnOOH}$. Mater Chem Phys 93:149-153. https://doi.org/10.1016/J.MATCH EMPHYS.2005.03.006

36. Liu Y, Wei J, Tian Y, Yan S (2015) The structure-property relationship of manganese oxides: highly efficient removal of methyl orange from aqueous solution. J Mater Chem A 3:19000-19010. https://doi.org/10.1039/C5TA05507E

37. Si X, Song X, Xu K et al (2019) Bovine serum albumin-templated $\mathrm{MnO}_{2}$ nanoparticles are peroxidase mimics for glucose determination by luminol chemiluminescence. Microchem J 149:104050. https://doi.org/10.1016/J.MICROC.2019.104050

38. Korsvik C, Patil S, Seal S, Self WT (2007) Superoxide dismutase mimetic properties exhibited by vacancy engineered ceria nanoparticles. Chem Commun 10:1056. https://doi.org/10.1039/ b615134e

39. André $\mathrm{R}$, Natálio $\mathrm{F}$, Humanes $\mathrm{M}$ et al (2011) $\mathrm{V}_{2} \mathrm{O}_{5}$ Nanowires with an intrinsic peroxidase like activity. Adv Funct Mater 21:501509. https://doi.org/10.1002/adfm.201001302

40. Zhang Y, Tian J, Liu S et al (2012) Novel application of CoFe layered double hydroxide nanoplates for colorimetric detection of $\mathrm{H}_{2} \mathrm{O}_{2}$ and glucose. Analyst 137:1325. https://doi.org/10.1039/ c2an00035k

41. Cao G-J, Jiang $X$, Zhang $\mathrm{H}$ et al (2017) Mimicking horseradish peroxidase and oxidase using ruthenium nanomaterials. RSC Adv 7:52210-52217. https://doi.org/10.1039/C7RA10370K

42. Shah J, Purohit R, Singh R et al (2015) ATP-enhanced peroxidase-like activity of gold nanoparticles. J Colloid Interface Sci 456:100-107. https://doi.org/10.1016/J.JCIS.2015.06.015

43. Wan Y, Qi P, Zhang D et al (2012) Manganese oxide nanowiremediated enzyme-linked immunosorbent assay. Biosens Bioelectron 33:69-74. https://doi.org/10.1016/j.bios.2011.12.033

44. Fan J, Yin J-J, Ning B et al (2011) Direct evidence for catalase and peroxidase activities of ferritin platinum nanoparticles. Biomaterials 32:1611-1618. https://doi.org/10.1016/j.biomateria Is.2010.11.004

45. Luo W, Zhu C, Su S et al (2010) Self-catalyzed, self-limiting growth of glucose oxidase mimicking gold nanoparticles. ACS Nano 4:7451-7458. https://doi.org/10.1021/nn102592h

46. He W, Liu Y, Yuan J et al (2011) Au@Pt nanostructures as oxidase and peroxidase mimetics for use in immunoassays. Biomaterials 32:1139-1147. https://doi.org/10.1016/J.BIOMATERIA LS.2010.09.040

47. Shah K, Bhagat $S$, Varade D, Singh S (2018) Novel synthesis of polyoxyethylene cholesteryl ether coated Fe-Pt nanoalloys: a multifunctional and cytocompatible bimetallic alloy exhibiting intrinsic chemical catalysis and biological enzyme-like activities. Colloids Surf A Physicochem Eng Asp 553:50-57. https:// doi.org/10.1016/J.COLSURFA.2018.05.034

48. Asati A, Kaittanis C, Santra S, Perez JM (2011) pH-Tunable oxidase-like activity of cerium oxide nanoparticles achieving sensitive fluorigenic detection of cancer biomarkers at neutral $\mathrm{pH}$. Anal Chem 83:2547-2553. https://doi.org/10.1021/ac102826k

49. Bhagat S, Srikanth Vallabani NV, Shutthanandan V et al (2018) Gold core/ceria shell-based redox active nanozyme mimicking the biological multienzyme complex phenomenon. J Colloid Interface Sci 513:831-842. https://doi.org/10.1016/J. JCIS.2017.11.064

SN Applied Sciences

A SPRINGER NATURE journal
50. Wang X, Yang Q, Cao Y et al (2016) Metallosurfactant ionogels in imidazolium and protic ionic liquids as precursors to synthesize nanoceria as catalase mimetics for the catalytic decomposition of $\mathrm{H}_{2} \mathrm{O}_{2}$. Chem A Eur J 22:17857-17865. https://doi.org/10.1002/ chem.201603743

51. Zhang W, Dong J, Wu Y et al (2017) Shape-dependent enzymelike activity of $\mathrm{CO}_{3} \mathrm{O}_{4}$ nanoparticles and their conjugation with his-tagged EGFR single-domain antibody. Colloids Surf B Biointerfaces 154:55-62. https://doi.org/10.1016/J.COLSU RFB.2017.02.034

52. Vallabani NVS, Singh S (2018) Recent advances and future prospects of iron oxide nanoparticles in biomedicine and diagnostics. 3 Biotech 8(6):279. https://doi.org/10.1007/s1320 5-018-1286-z

53. Patel P, Kansara K, Singh R et al (2018) Cellular internalization and antioxidant activity of cerium oxide nanoparticles in human monocytic leukemia cells. Int J Nanomed 13:39-41. https://doi. org/10.2147/IJN.S124996

54. Singh R, Karakoti AS, Self W et al (2016) Redox-sensitive cerium oxide nanoparticles protect human keratinocytes from oxidative stress induced by glutathione depletion. Langmuir 32:12202-12211. https://doi.org/10.1021/acs.langmuir.6b03022

55. Liu Y, Wu H, Li M et al (2014) pH dependent catalytic activities of platinum nanoparticles with respect to the decomposition of hydrogen peroxide and scavenging of superoxide and singlet oxygen. Nanoscale 6:11904-11910. https://doi.org/10.1039/ C4NR03848G

56. Du J-Z, Du X-J, Mao C-Q, Wang J (2011) Tailor-made dual pHsensitive polymer-doxorubicin nanoparticles for efficient anticancer drug delivery. J Am Chem Soc 133:17560-17563. https ://doi.org/10.1021/ja207150n

57. Boelrijk AEM, Dismukes GC (2000) Mechanism of hydrogen peroxide dismutation by a dimanganese catalase mimic: dominant role of an intramolecular base on substrate binding affinity and rate acceleration. Inorg Chem 39:3020-3028. https://doi. org/10.1021/ic9911771

58. Batinić-Haberle I, Rebouças JS, Spasojević I (2010) Superoxide dismutase mimics: chemistry, pharmacology, and therapeutic potential. Antioxid Redox Signal 13:877-918. https://doi. org/10.1089/ars.2009.2876

59. Alarifi S, Ali D, Alkahtani S (2017) Oxidative stress-induced DNA damage by manganese dioxide nanoparticles in human neuronal cells. Biomed Res Int 2017:1-10. https://doi. org/10.1155/2017/5478790

60. Hussain SM, Javorina AK, Schrand AM et al (2006) The interaction of manganese nanoparticles with PC-12 cells induces dopamine depletion. Toxicol Sci 92:456-463. https://doi.org/10.1093/toxsc $\mathrm{i} / \mathrm{kfl020}$

61. Singh SP, Kumari M, Kumari SI et al (2013) Toxicity assessment of manganese oxide micro and nanoparticles in Wistar rats after 28 days of repeated oral exposure. J Appl Toxicol 33:1 165-1179. https://doi.org/10.1002/jat.2887

62. Hafez AA, Naserzadeh P, Ashtari K et al (2018) Protection of manganese oxide nanoparticles induced liver and kidney damage by vitamin D. Regul Toxicol Pharmacol 98:240-244. https://doi. org/10.1016/J.YRTPH.2018.08.005

63. Yousefalizadegan N, Mousavi Z, Rastegar T et al (2019) Reproductive toxicity of manganese dioxide in forms of micro- and nanoparticles in male rats. Int J Reprod Biomed (Yazd, Iran) 17:361. https://doi.org/10.18502/ijrm.v17i5.4603

Publisher's Note Springer Nature remains neutral with regard to jurisdictional claims in published maps and institutional affiliations. 